International Journal of Computer and Information System (IJCIS)

Peer Reviewed - International Journal

Vol : Vol. 01, Issue 03, November 2020

e-ISSN : 2745-9659

https://ijcis.net/index.php/ijcis/index

\title{
Analysis Of Kids Garden Dapodic Application System
}

\author{
$1^{\text {st }}$ Annisaa Miftakhul Jannah, $2^{\text {nd }}$ Muqorobin, $3^{\text {rd }}$ Wahyu Wijaya Widiyanto \\ ${ }^{1,2}$ Institut Teknologi Bisnis AAS Indonesia Surakarta \\ ${ }^{3}$ Politeknik Indonusa Surakarta \\ ${ }^{1,2}$ Jl. Slamet Riyadi No. 361 Windan, Makamhaji, Kartasura, Sukoharjo, Indonesia \\ ${ }^{3}$ Jl. K.H Samanhudi No.31, Bumi, Kec. Laweyan, Kota Surakarta, Jawa Tengah 57149 \\ ${ }^{1}$ annisaamiftakhul68@gmail.com, ${ }^{2}$ robbyaullah@gmail.com, ${ }^{3}$ wahyuwijaya@ poltekindonusa.ac.id
}

\begin{abstract}
The dapodic system application is a system application that makes it easy for school users or operators to input all types of data related to school, such as active teacher data, non-active teacher data, active student data, non-active student data, report cards, schedules, and school facilities and infrastructure. The purpose of this research is to analyze how kindergarten school management is implemented with the dapodic application. The first method used is the data collection method, data analysis method, and system application implementation. The end result of this research is a perfect and maximum dapodic application that makes it easier for users to do their work.
\end{abstract}

Keywords - Analysis, Applications, Systems, Dapodik, Kindergarten

\section{INTRODUCTION}

Technological developments continue to increase along with human needs. Technology can not be denied that it is very helpful in solving any problems that exist in everyday life. With the existence of various applications that are smart and can help with the tasks that must be done by humans.

J\&T Express is a company engaged in the delivery of goods, both shipping by land, sea or air, which was just established on August 20, 2015. In addition to package delivery, J\&T Express has free package pick-up services on the spot, so consumers no longer need come to the drop point to deliver goods and packages.

Basic Education Data (Dapodik) is an integrated national scale data collection system, and is the main source of national education data, which is part of the national education planning program in realizing intelligent and competitive Indonesians. Because without careful educational planning, all programs formed from this plan will be far from the expected goals. To carry out educational planning, as well as to carry out educational programs on target, fast, complete, valid, accountable and up to date data are needed. With the availability of data that is fast, complete, valid, accountable and up to date, the process of planning, implementing, reporting and evaluating the performance of national education programs can be carried out in a more measured, targeted, effective, efficient and sustainable manner. In this regard, the Ministry of National Education has developed an integrated national scale data collection system called Basic Education Data (Dapodik).

The Dapodik application was built to obtain quality data and this data will later determine central government policies in determining such as the ratio of education personnel, the requirements for determining the teaching professional allowance (TPG), School Operational Costs (BOS) and many other central policies later it will take data from the Dapodik application, therefore the teaching unit must input data and update data according to the physical evidence that is in the Dapodik application. The principal as the leader in the education unit is responsible for all data that has been inputted or entered into Dapodik. So the principal must know the uses and features of Dapodik.

\section{RESEARCH METHODS}

The following data collection methods are as follows: Research Approach and Technique : The approach in this research is quantitative research where the observations made include everything related to the object of research, phenomena and correlations that exist among them and are presented in figure form. Data Retrieval Techniques : The data collection techniques in this research plan are as follows : Interview, In this stage the writer interviewed Mrs. Lina as the school operator at TK Dharma Wanuta I Ngadirejo. The topic of the interview that was carried out was how the dapodic application was operated and what the dapodic application was like. The interview was conducted at TK Dhharma Wanita I Ngadirejo. Observation

In the observation stage, the writer observes how the dapodic application works. Literature review I collect data from examples of journals that already exist, the internet, and interviews with sources.

The following methods in system development are as follows: System Planning, Planning for the dapodic application system is carried out by grouping master data, including teacher data and student data, then using predetermined methods to process teacher and student data into the system and generate reports on teacher and student data who are still active. System Analysis, In this system analysis stage the author will discuss the steps for making a dapodic system, namely: 1) Intelligent stage : This stage is the process of tracing and identifying problems. The data obtained is data that can be used to assist the decisionmaking process. The data contains nis, student name, gender, class, date of birth and address. 2) Design stage : This stage is the stage where the process of selecting students and teachers is carried out based on existing criteria. 3) Election Stage (Choice) : This stage is the analysis stage of selecting students and teachers who are still active using the available system. 4) Implementation Stage (Implementation) : This stage is the application phase of the phase that has been designed to become a dapodic system application. 5) System Design : In this stage the writer will make a system design consisting of. 
International Journal of Computer and Information System (IJCIS)

Peer Reviewed - International Journal

Vol : Vol. 01, Issue 03, November 2020

e-ISSN : 2745-9659

https://ijcis.net/index.php/ijcis/index

\section{RESULT AND ANALYSIS}

In the discussion, discussing the results of research in the form of system design as a whole are as follows :

\subsection{Computerized System Analysis}

System analysis is a process to determine the problems that must be faced. TK Dharma Wanita I Ngadirejo Kindergarten requires an application to input teacher and student data. For this reason, a computerized application system is needed so that it can make it easier to determine students and teachers who are still active and non-active.

\subsection{System Design}

The design of this system is to meet the needs of system users and provide a clear picture of the computer program that will build the new system.

1. Context Diagram

The context diagram (CD) for dapodic applications is as.

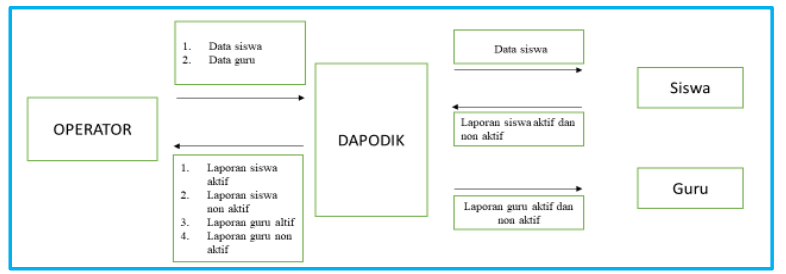

Figure 1. Context Diagram

2. HIPO

HIPO (Input Process Output Hierarchy) is a system development tool and system documentation technique in programs. The most important goal of HIPO is to produce correct output and meet user requirements.

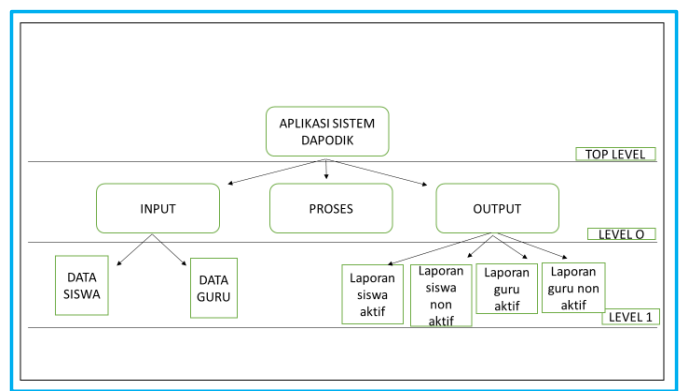

Figure 2. HIPO (Input Process Output Hierarchy)

3. DAD

Data Flow Diagram (DAD) is a flow diagram that describes the flow from data to the system, DAD helps to understand the system in a logical, structured and clear manner.

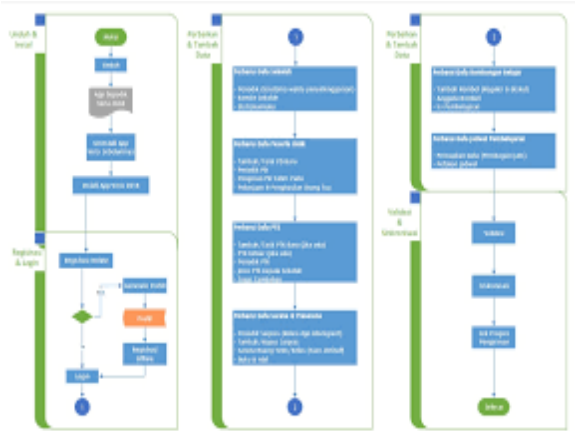

Figure 3. DAD (Data Flow Diagram)
4. System Implementation

System implementation is the process of making a system in the form of designing a dapodic system application:

1. Login

The dapodik application login page display can be as follows.

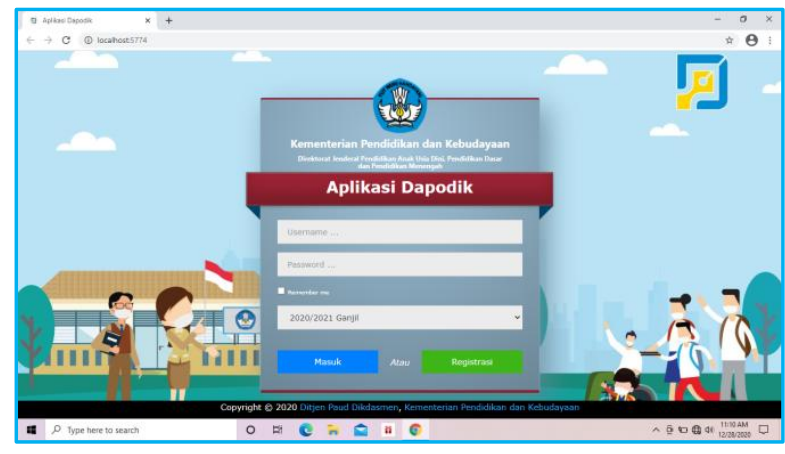

Figure 4. Login System Dapodik

2. Dapodic Home View

The initial view goes into the dapodic system after logging in.

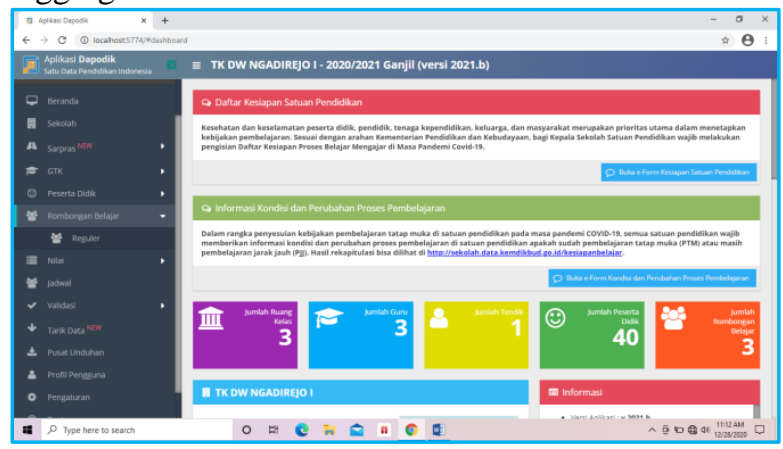

Figure 5. Dashboard System

3. Appearance of Dapodic Teacher

This page is a display of the Teacher menu which displays active and inactive teacher data.

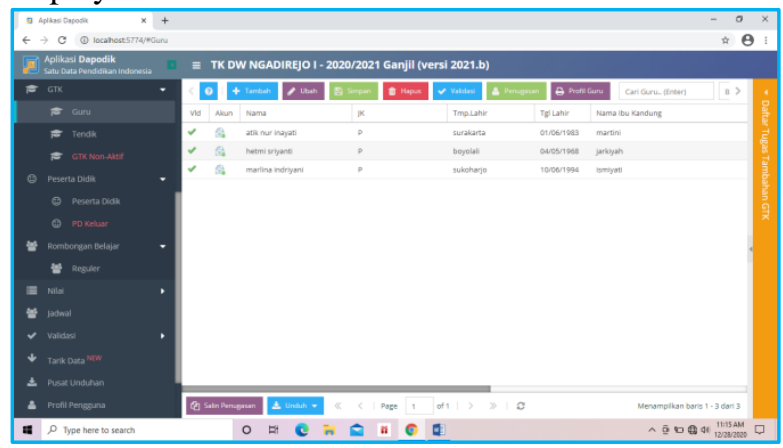

Figure 6. Active Teacher Display

4. Student Display

This page is a display of the student menu. Here is a look at it. 
International Journal of Computer and Information System (IJCIS)

Peer Reviewed - International Journal

Vol : Vol. 01, Issue 03, November 2020

e-ISSN : 2745-9659

https://ijcis.net/index.php/ijcis/index

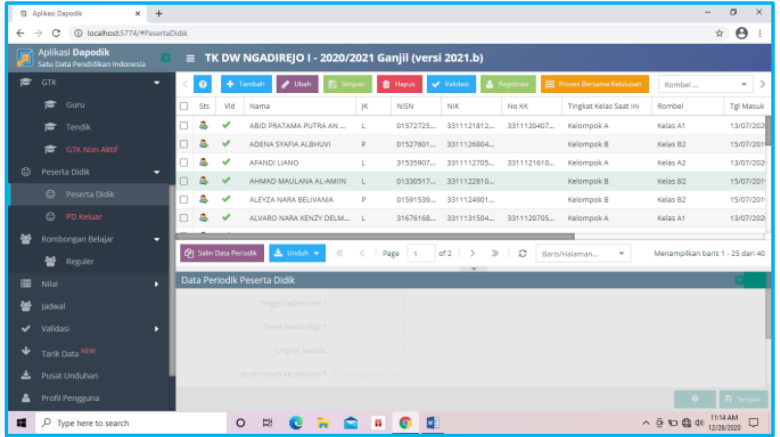

Figure 7. Students View

\subsection{System Testing}

Testing is a system test process at the end which is also useful for testing the system. There are two system tests, namely the functionality test and the validity test. following the test.

1. Functionality Testing

Functionality testing uses the Black Box, which is useful for knowing the output results in each form in the program system. following the results of the recapitulation.
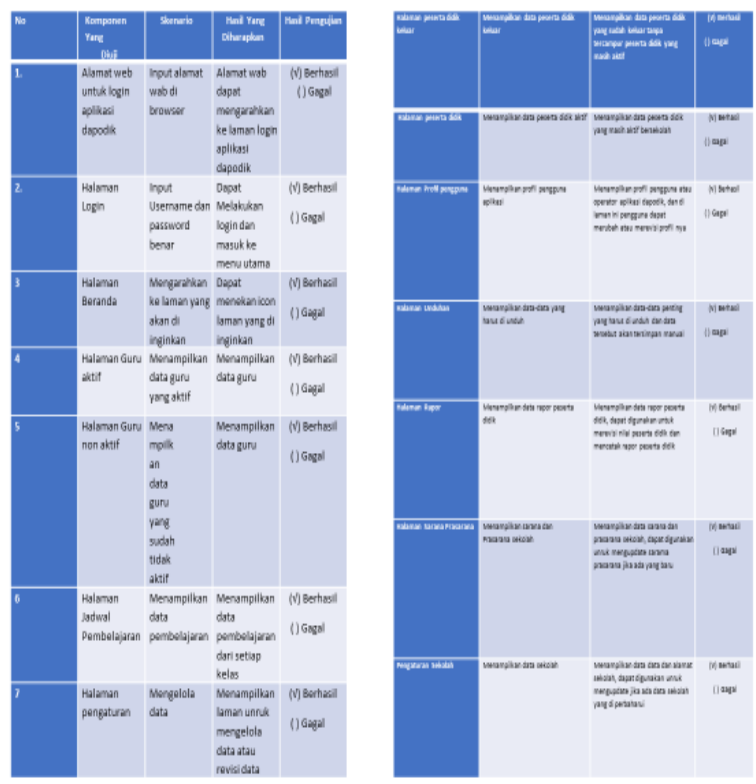

Figure 8. Black Box Testing

\section{Quizoner Testing}

In the questionnaire test, write down the concept steps and the testing model. The explanation can be made like a list of stages at the end of a sequence. In the process of determining a questionnaire test for this system, several respondents were involved.

\begin{tabular}{|c|c|c|c|c|c|}
\hline \multicolumn{6}{|c|}{ ASPEK PERTANYAAN DAN HASIL PENGUJIAN } \\
\hline $\begin{array}{l}\text { Aspek } \\
\text { pertanyan } \\
\text { No.1 }\end{array}$ & \multicolumn{5}{|c|}{$\begin{array}{l}\text { Apakah dengan aplikasi ini memudahkan anda dalam meng input data siswa dan } \\
\text { guru? }\end{array}$} \\
\hline $\begin{array}{l}\text { Kategori } \\
\text { Jawaban }\end{array}$ & $\begin{array}{l}\text { Sangat } \\
\text { Setuju }\end{array}$ & Setuju & $\begin{array}{l}\text { Cukup } \\
\text { Setuju }\end{array}$ & $\begin{array}{l}\text { Tidak } \\
\text { Setuju }\end{array}$ & $\begin{array}{l}\text { Sangat Tidak } \\
\text { Setuju }\end{array}$ \\
\hline Responden & 30 & 10 & 0 & 0 & 0 \\
\hline Sampel & 40 & 40 & 40 & 40 & 40 \\
\hline Jumlah & \multicolumn{5}{|c|}{$(30 \times 5)+(10 \times 4)+(0 \times 3)+(0 \times 2)+(0 \times 1)=190$} \\
\hline Hasil & \multicolumn{5}{|c|}{$190 / 40=4.75$} \\
\hline \multicolumn{3}{|c|}{ Sang Tidak Setuju } & \multicolumn{3}{|c|}{ Sangat Sel } \\
\hline & 2 & 3 & 4 & 4.75 & 5 \\
\hline
\end{tabular}

Figure 9. Questionnaire Test

\section{CONCLUSION}

At the end of this pentup is made in the form of conclusions and suggestions, namely as follows: Based on the evaluation process that has been carried out, it can be concluded that the dapodic system provides convenience to the user. This can prove that if the value of the factor of convenience to benefit increases, user acceptance of the information system will also increase. Thus the ease of the information system on its usefulness affects the acceptance of the Dapodik information system, where school operators have the perception that using the Dapodik Application can make it easier for school operators to report school data in an updated manner and provide benefits that make work easier to do. Along with the development of the era, the difficulty of data collection in the education system in Indonesia has been made easier with the Dapodik Application. It is fitting that this facility is properly utilized so that the data collection process in schools can be carried out properly so that it can create a well-organized education system too.

\section{REFERENCES}

[1] Dalimunthe Nurmaini, Meflinda Astuti, Azmi Syahrul, 2014. Analysis of the Effect of Ease and Benefit Factors on Acceptance of Basic Education Data Information System Users, Pekanbaru Riau.

[2] Daniati, Erna, 2017. The Committee's Task Allocation System Uses the Assignment Method. JSI. Kediri.

[3] Hariyanto, Bambang, (2004), Database Management Systems, Informatics, Bandung.

[4] Indrajani. (2011). Database Design in All in 1, PT. Elex Media Komputindo, Jakarta.

[5] Jogiyanto, HM. 1995. Analysis and Design of Information Systems \& Structured Approaches Theory and Practice of Business Applications. ANDI: Yogyakarta.

[6] Kristanto, Andri, 2003, Designing Information Systems and Its Applications, Publisher: Gava Media, Jakarta.

[7] Lesmana Chandra, Arifin Ardian, Santoso Danar, 2016. The Level of Understanding of School Operators in Dapodik Applications in South Pontianak District, Pontianak

[8] Munawar. (2005), Visual Modeling with UML, Graha Ilmu, Yogyakarta, 17-100. 
International Journal of Computer and Information System (IJCIS)

Peer Reviewed - International Journal

Vol : Vol. 01, Issue 03, November 2020

e-ISSN : 2745-9659

https://ijcis.net/index.php/ijcis/index

[9] Nugroho, Adi, 2004, the concept of database system development, Bandung: Bandung Informatics.

[10] Nugroho, Adi. "Design and Implementation of Database Systems". Yogyakarta: Andi, 2011

[11] Saputra Anggi, Fatoni, Ariandi M., 2016. Analysis of Computer Network Infrastructure Dapodic Systems in SMA in Prabumulih City using the Top Down Method, Palembang.

[12] Wijonarto Setyo Sigid, 2017. Evaluation of ICT Operators' Ability in Filling in Basic Education Data (Dapodik), Salatiga.

[13] Muqorobin, M., \& Rais, N. A. R. (2020, November). ANALISIS PERAN TEKNOLOGI SISTEM INFORMASI DALAM PEMBELAJARAN KULIAH DIMASA PANDEMI VIRUS CORONA. In Prosiding Seminar Nasional \& Call for Paper STIE AAS (pp. 157-168).

[14] Utomo, I. C., Rokhmah, S., \& Muslihah, I. (2020). Web Based Distribution of Zakat, Infaq, and shodaqoh (Case Study Of Surakarta City Region). International Journal of Computer and Information System (IJCIS), 1(1).

[15] Muqorobin, Muqorobin, Siti Rokhmah, Isnawati Muslihah, and Nendy Akbar Rozaq Rais. "Classification of Community Complaints Against Public Services on Twitter." International Journal of Computer and Information System (IJCIS) 1 , no. 1 (2020).

[16] K. Kusrini, E. T. Luthfi, M. Muqorobin and R. W. Abdullah, "Comparison of Naive Bayes and K-NN Method on Tuition Fee Payment Overdue Prediction," 2019 4th International Conference on Information Technology, Information Systems and Electrical Engineering (ICITISEE), Yogyakarta, Indonesia, 2019, pp. 125-130, doi: 10.1109/ICITISEE48480.2019.9003782.

[17] Muqorobin, M., Hisyam, Z., Mashuri, M., Hanafi, H., \& Setiyantara, Y. (2019). Implementasi Network Intrusion Detection System (NIDS) Dalam Sistem Keamanan Open Cloud Computing. Majalah Ilmiah Bahari Jogja, 17(2), 1-9.

[18] Muqorobin, M., Apriliyani, A., \& Kusrini, K. (2019). Sistem Pendukung Keputusan Penerimaan Beasiswa dengan Metode SAW. Respati, 14(1).

[19] Abdullah, Robi W., et al. "Keamanan Basis Data pada Perancangan Sistem Kepakaran Prestasi Sman Dikota Surakarta." Creative Communication and Innovative Technology Journal, vol. 12, no. 1, 2019, pp. 13-21. 